\title{
STRUCTURAL STUDY OF PEPACCUR ORAL LITERATURE LAMPUNG PEPADUN COMMUNITIES IN THE PROCESSION OF TAKING CUSTOM DEGREE
}

\author{
Dewi Ratnaningsih \\ dewi.ratnaningsih@umko.ac.id
}

\section{Indonesian Language and Literature Education Department, University of Muhammadiyah Kotabumi, Lampung}

\begin{abstract}
Pepaccur is a type of Lampung poetry which contains advice or message in the customary degree ceremony. In this research, data was collected from several regions belonging to the Lampung Abung community, such as Kotabumi llir, Blambangan Pagar, Surakarta, Bumi Agung, and Mulang Maya. The problem that will be examined in this study is about the structure contained in Pepaccur. The purpose and benefits of this study are (1) to determine the Pepaccur structure in the Pepadun community in the procession of taking traditional titles; (2) to revitalize Pepaccur Lampung Pepadun people. Descriptive method through qualitative approach is the method used in this study. Data collection techniques used in this study are (1) observation, (2) recording, and (3) interview. Data analysis techniques are carried out by identifying the Pepaccur structure. Based on ethnographic studies that are used as a foothold in this study the Pepaccur structure consists of a framework, diction, sound, tone, and class. (1) Pepaccur framework. Of the 6 Pepaccur text samples, there is only one Pepaccur text that does not have an opening stanza, ie in Pepaccur II text. In addition, the Pepaccur II text is also a text in the form of stories to bind Lampung women. (2) Pepaccur's diction. Based on the results of the analysis, the diction used by people who are Pepaccur is a diction related to marriage. (3) Pepaccur sounds. the sound found in Pepaccur text analysis is a sound pattern abc / $a b c, a b / a b$, aa / aa, a / a. (4) Pepaccur tones. The tone in Pepaccur's text is advising. (5) figurative language. The figurative language found in the Pepaccur text includes; allegory, metaphor, and simile.
\end{abstract}

Keyword: Pepaccur, Lampung Poetry, Language Structure

\section{INTRODUCTION}

Literature is an inseparable part of society. The existence of literature hints at the creativity and productivity side of society. Based on the way it is delivered, literature is divided into two, namely oral literature and written literature. Oral literature is a form of literature that is done directly or by word of mouth; whereas, written literature is a form of literature delivered through written word. 
This article will discuss about oral literature in Lampung Pepadun society in the form of poetry, namely Pepaccur. Pepaccur is a type of Lampung poetry in which there is advice or message in a traditional title award ceremony (Sanusi, 2010: 70). The society of Pepadun is devided into four region: 1) Abung, 2) Tulang Bawang, 3) Way Kanan/Sungkai, dan 4) Pubiyan (Hadikusuma, 2009:5). In this study, Lampung Abung community will be specialized as the object of the research. Lampung Abung people are spread in several regions. In this study data will be collected from several areas belonging to the Lampung Abung community, such as Kotabumi llir, Blambangan Pagar, Surakarta, Bumi Agung, and Mulang Maya.

The Pepadun society has two dialects, namely $\mathrm{A}$ (api) and $\mathrm{O}$ (nyo) dialects. Way Kanan/Sungkai Way community uses $A$ (api) dialect, and Tulang Bawang and Abung communities use $\mathrm{O}$ (nyo) dialect. Based on the distribution of these dialects, it can be seen that the object in this study is Lampung-speaking Pepaccur uses $\mathrm{O}$ (nyo) dialect. Pepaccur is one type of Lampung poetry which contains advices. Advice given through Pepaccur is carried out in the procession of awarding customary titles.

\section{LITERATURE REVIEW}

The granting of a traditional title is a hereditary tradition carried out by the people of Lampung. The granting of a customary title is done when the Lampung people relinquish their single period (marriage). The granting of a traditional title can be done at the bride or groom's place. The granting of a customary title at a woman's place is usually referred to as ngamai adek/adok. If done in a man's place, it is known as nandekken adek dan inai adek/nandokkon adok ghik ini adok. Through Pepaccur the parents will provide advices on community life as well as family. This is relevant to the results of research and the opinion of Sukmawati et al, (2014: 2) that the message contained in Pepaccur is related to the life of a household, community, nation, state and religion. In addition, Sanusi (2010: 71) says Pepaccur contains advice on housing, society, race, nation, and religion. The issues to be considered in this article is about the structure found in Pepaccur. Basically the structure of Pepaccur is the same as the structure of poetry because Pepaccur is a type of Lampung poetry. Waluyo (2013: 1) said poetry is a literary work that is compacted, shortened, and given a rhythm with a unified sound and selection of words (imaginative). Likewise Pradopo (2010: 314) argues that poetry is indirect speech or expression. Pepaccur in each text has a structure like poetry in general. Siswantoro in Armina (2014: 262) said the intrinsic elements of poetry include diction, language style, imaging, tone of voice, rhythm, rhyme, poetry form, alliteration, asonance, consonance, relationship of 
meaning, and sound. Wolosky in Malik (2012: 34), argues that the structure or elements of poetry consist of a choice of words, wording, sounds, stops, images, and figurative language. Based on the opinion of experts, this research will be directed to the structure of poetry in the form of a Pepaccur framework, choice of words (diction) and word order (syntax), sound, tone and figurative language.

\section{RESEARCH PROCEDURES}

The aims and benefits of this research are (1) to find out the structure of Pepaccur in the Pepadun community in the procession of taking customary titles;

(2) to revitalize Pepaccur Lampung Pepadun community. Descriptive method through a qualitative approach is the method used in this study. Data collection techniques used in this study were (1) Observation, (2) Recording, and (3) Interviews.

Observation is the process of observing Pepaccur activities carried out in taking customary titles. Jaya (2017) Observations were made to obtain field notes during the implementation process of giving customary titles. The recording of Peppacur was carried out by the researcher using an audio-visual recording device, then the results of the recording were transcribed in written form. Peppacur that has been recorded and transcribed will be analyzed. The analysis will be focused on the structure and values. Interviews were conducted to dig information about the meaning, structure and values in Pepaccur.

\section{FINDING AND INTERPRETATION}

\section{Structure in the Pepaccur}

1. Pepaccur Framework

The Pepaccur Framework is a structural form of a Pepaccur. The Pepaccur structure consists of opening, filling, and closing stanzas. The opening stanza is usually in the form of greetings, prayers, thanksgiving and so on. The stanza is in the form of advice you want to give, and the closing stanza usually contains a closing greeting or an apology.

\section{a. Opening Verse}

Based on the results of an interview conducted on June 6, 2018, Lampung Artists, Supirman AS revealed that the Pepaccur structure consisted of opening lines, advice or content, and closing. The first stanza in a Pepaccur can be in the form of thanksgiving and offering prayers to the bride. Gratitude and giving of prayers are a form of joy/joy over the marriage of family members. This can be seen from the quote below.

Syukur alhamdulilah Tigeh
judeumeu tano Dendeng segalo
badan Kekalau metei wo tuah
Ino sai upo duo
Kiluan adek tuhan

Thank God, now your soul mate arrives to all family I hope you all have good luck That is our prayer Which is begged to God 
Based on the results of an interview conducted on July 1, 2018, Syaidah gelar Suntan Ratu Bayunan revealed that the first stanza in a Pepaccur could be a request for permission to all other officers. This can be seen in the quote below.

Excuse me Tabik pun para misi Hikam nondokko sarana Ke kalau dapek nuli Ram dapok bahagia

This is a suggestion

Who knows, can get a partner

We can be happy

\section{b. Content Verse}

The contents of the verse include a variety of variations of Pepaccur which can be seen from the point of purpose or purpose of giving Pepaccur. Disclosure of Pepaccur's diverse contents due to the variety of advice you want given to the bride and groom who will be given the title. The contents contained in the Pepaccur can be in the form of advice about religion. Quotes of the Pepaccur regarding religious advice can be seen in the quotation below.

Pertamo, beribadah Sembayang wakteu limo Dang sappai ketinggalan Kiri munih Fatihah Tehadep sai kak meno Kapak sai lagei tengan

First, worship

Praying five times

Do not be left

Send also fatimah

For the deceased

Nor are those still alive
The contents in Pepaccur can also be in the form of stories about life, stories about the application process, and other stories. The contents contained in the text of Pepaccur II about the story of a man and woman who are already bound together. The following is form of Pepaccur II about the story about the union of a man and woman in marriage boundary.

Masang niku sirok, kukuh mak gubar lagi Sirok mu sirok lekok, sirok dang gubang lagi

Kite kuti haga nyegok, dapok ridek dija ji Kita ngebubar sirok, hikam ngusung pulisi

Attached you are bound, sturdy not loose again

Your tie is tied tightly, the tie is no longer dispersed

If you want to see, you can come closer here

If you want to untie us, we bring the police

\section{c. Closing Verse}

The closing verse is the last verse found in Pepaccur. The closing lines on Pepaccur are indicated by Pepaccur's statement/statement will be finished. Sometimes it also contains an apology and message/message to the listener. Following is an example of the Pepaccur closing stanza.

Sijo akhir petuah Ingekken dang lupo Akuk jadei anggeuan Nyo maknono kidah Seghem matei di gulo Pahemken metei sayan

This is the end of advice Remember not to be forgotten Take hold of what it means 
Ants die from sugar

Interpret by your own

The following is an example of the Pepaccur, which the final marker forms apologies to the listeners and a request for forgiveness from the God Almighty.

Lamun wat salah kata, Munih wat salah susun, Pisaan sai cak diya, Hikam bulajagh pantun

Ya Allah..tabik pun kilu ampun, Pusekam pandai dia, Jama kuti sai unyin, Mehaf pun ngalimpugha

If there is a wrong word, it is also wrong stacking, which is said, we learn rhymes

$$
\begin{array}{r}
\text { O Allah, beg for mercy, } \\
\text { you know } \\
\text { to all of you, }
\end{array}
$$

\section{Diction}

The diction used in Pepaccur uses many related dictions with the problem of uniting the relationship between male and female or commonly referred to as marriage. The following is an example of the Pepaccur, related to the diction.

Thank God now your soul mate arrives Now your soul mate arrives I hope you all have good luck
In addition, diction is used in Pepaccur uses a lot of diction related to the story of one's struggle to love her lover. The following is a quote from the Pepaccur, related to the diction.

\section{Inggok nyak minggu likut Waktu nyak lapah manjau Badanku jadi liput Bak ulah kena alau,}

Ayah salah penenggis Adek teduhni nanggis Badanku rikras-rikris Di bedak makai linggis,

I remember last week When I was on a date My body got dirty Because chased

Daddy miss-heard Sister is thought to cry My body is injured Chased by crowbar

\section{Sound}

Pepaccur has a rhyme or sound pattern that is in harmony. Rhymes or sound patterns in Pepaccur are abc / abc and $a b / a b$. Rhyme harmony or deep sound patterns. These Pepaccur effects are what makes unique pattern-interesting sound. The aesthetic value of Pepaccur is seen in the formation of words with similar sounds at the end of words. Here is an example of Pepaccur with rhymes or abc / $a b c$ and $a b / a b$ sound patterns.

\footnotetext{
Syukur alhamdulilah Tigeh judeumeu tano Dendeng segalo badan Kekalau metei wo tuah Ino sai upo duo Kiluan adek tuhan
} 
Thank God, now your soul mate arrives to all family

I hope you all have good luck

That is our prayer

Which is begged to God

Besides rhyme, there is also rhythm in Pepaccur. The algorithm is a form over and over from letters, syllables, or words made by people who have Pepaccur. The algorithm in the Pepaccur seen in the following quote.

\section{Syukur alhamdulilah Tigeh judeumeu tano Dendeng segalo badan Kekalau metei wo tuah Ino sai upo duo Kiluan adek tuhan}

Thank God, now your soul mate arrives to all family

I hope you all have good luck

That is our prayer

Which is begged to God

In tthe quote Pepaccur above, the letter ' $\mathrm{O}$ ' is repeated. The repetition of the letter "०" is a sign of the rhythm in the Pepaccur. The repetition of the letter ' $O$ ' occurs because of the dialect of the source and place of data collection.

\section{Tone}

Tone is the poet's attitude towards the reader. In the poetry text there is communication between the poet and the reader. The tone is related to the poet's attitude towards the reader. The poet is patronizing, advising, mocking, insinuating, or being straightforward only tells the reader something.
The tone contained in the Pepaccur is to ask for prayer for male and female couples who are going to get married and who are given the title. The prayer offered by people with Pepaccur is that they (male and female partners) can have good fortune and be fortunate in married life. The following is an example of a quote from the Pepaccur.

\section{Syukur alhamdulilah Tigeh judeumeu tano Dendeng segalo badan Kekalau metei wo tuah Ino sai upo duo Kiluan adek tuhan}

Thank God, now your soul mate arrives to all family I hope you all have good luck That is our prayer Which is begged to God

Apart from prayer, the attitude of people who have Pepaccur can also be in the form of advice. The following is an example of the Pepaccur in which the attitude of the person with Pepaccur provides advice. Whose advice given can be a way to behave deeply married, must always obey the older, relent to the younger, do not disobey the commands of older people, and not to say lazy. This can be seen in quote the Pepaccur below.

Pandai-pandai memalah

Patuh di waghei tuho Uyang najin keminan

Basing upo perittah

Dang cawo mak kuwawo Ino pebalahan patangan

Cleverly relent 
obedient to the eldest

brother's wife's brother and aunt

Whatever is ordered

Don't say lazy

That's shy

\section{Figurative Language}

Figure of speech is the most important part in poetry. The poet conveys the message in symbolic form. To capture the messages of the reader or listener combined with figurative language. Figurative language takes the form of expressions at the level of connotative meaning. The figurative language used in the Pepaccur includes: allegory, metaphor, and simile.

The figurative language contained in the Pepaccur text is allegory (stated in another way, through figuratively or depiction). The words that become indicators are the words in the fourth, fifth and sixth stanzas. The word is Tuah nyepik in kukeu (Tuah slipped on the nail), Ules ninding in the body (happiness always accompanies), and rezekei tawit milet (sustenance always flowing). The word is a word used by people who are Pepaccur, to express their advice using imagery. The quotation below is a quotation that supports the statement.

Tano tigeh judeumeu Memugo matei wo rawan Tigeh alam salah mei

Tuah nyepik di kukeu Ules ninding dibadan Rezekei tawit milet
Now your soul mate is up.

Hopefully you have good until the afterlife

Tuah slipped on the nails Happiness always accompanies sustenance always flowing

The figurative language contained in the Pepaccur is a metaphor (forms made explicitly do not have meaning but can explicitly represent another purpose based on equality or comparison). The words that become indicators are the words in the fifth verse. The word is Makkung nyak ghantop mejong (not yet seated warmly). Besides that, simile figurative speech are also found explicitly (clearly) between two things use conjunctions, like, like, for example, like, like and so on). The words that become indicators are the words in the seventh verse. The word is Ibaragh bunga Mawagh (Like a rose), Mekagh dipagi ghani (blooms in the morning). The word is a word used by people who have Pepaccur, to express their advice using the simile form. The quote below is a quote

support the statement.

Makkung nyak ghantop mejong,

Niku adik kak luah,

Ku helauko penontong,

Ghupa sikop ghik wahwah,

Ibaragh bunga mawagh,

Mekagh dipagi ghani,

Sikop mak pantagh tawagh,

Ngeguai senang hatiku

Not yet warm, sitting, your sister is out.

I have a nice and bright appearance 
Like a rose blooming in the morning Beautiful never fades

Make my heart happy

\section{CONCLUSION}

The framework in the Pepaccur consists of opening, content and closing verse. From the results of the analysis, all of the Pepaccur frameworks are contained in it. On the contents verse, almost all Pepaccur contains advice. However, the research findings obtained in one of the Pepaccur, the contents verse contains a description of the story to tie Lampung women by giving precious metals (gold).

Diction in the Pepaccur uses many dictions related to the problem of the union of relations between men and women or commonly referred to as marriage. In addition, the use of diction is related to the problem of refusing someone's love with a woman who is loved sometimes in the Pepaccur.

Pepaccur has a rhyme or sound pattern that is in harmony. The rhymes or sound patterns in Pepaccur are abc / abc, $a b / a b$, aa / aa, and a / a. The sound patterns form the harmony of sound in Pepaccur, this is what makes an interesting sound pattern effect.

The tone contained in the Pepaccur text is very diverse. This depends on what will be delivered by people who Pepaccur. The tone contained in the Pepaccur text is 1) asking for prayer for male and female couples who are going to get married and who are given the title, 2) 3 tells about the process 'Binds' women to men, 3 ) tells the refusal of someone's love with the woman he loves, 4) is tolerant in dealing with the problem and 5) tells about the struggle to love someone.

Figure of speech is the most important part in poetry. The poet conveys the message in symbolic form. To capture the messages of the reader or listener combined with figurative language. Figurative language takes the form of expressions at the level of connotative meaning. The figurative language in the Pepaccur text include; allegory, metaphor, and simile. This figurative language is used as a symbolic form of people who Pepaccur to give advice to people who are given advice.

\section{REFERENCES}

Armina. 2014. Structures of The West Lampung Wayak's Oral Literarure. http://artikel.ubl.ac.id/index.php/i cel/article/download/293/295

Sanusi, Effendi. 2010. Sastra Lisan Lampung. Bandar Lampung: Universitas Lampung.

Hadikusuma, Hilman. 2010. Bahasa Lampung. Bandar Lampung: PT. Fajar Agung. 
Malik, S.Harto. 2012. Lohidu sebagai Ragam pantun pada Masyarakat

Gorontalo (Disertasi). Jakarta: Universitas Negeri Jakarta.

Jaya, A. 2017. The Influence of Teachers'

Questioning Strategies on the Eleventh

Grade Students' Speaking

Achievement at SMKN 1

Palembang.Jambi-English Language

Teaching. 2 (1).

Pradopo, Rachmad Djoko. 2010.

Pengkajian Sastra. Yogyakarta:

Gadjahmada University

Press.

Sukmawati dkk. 2014. Pepaccur pada

Masyarakat lampung Pepadun dan

Kelayakannya

sebagai Materi Pembelajaran.

http://jurnal.fkip.unila.ac.id/index.php/BIND

O/arti

cle/download/5825/3590

Waluyo, J. Herman (2013). Apresiasi Sastra:

Untuk Pelajar dan Siswa. Jakarta: Gramedia

Pustaka Utama. 